УДК 021:001.891

Копансва Вікторія Олександрівна, кандидат історичних наук, директор Наукової бібліотеки

Національної академії керівних кадрів культури і мистецтв vkopaneva@ukr.net ORCID ID: 0000-0001-9838-4855

\title{
КОНЦЕПТУАЛЬНА МОДЕЛЬ БІБЛІОТЕКИ В СЕРЕДОВИЩІ ЦИФРОВОЇ НАУКИ
}

Мета роботи - дослідження спрямоване на визначення та кониентроване представлення функиіональної структури бібліотеки, основне призначення якої полягає в забезпеченні системноінтеграчійної взаємодії науково-дослідної і бібліотечно-інформаційної діяльності в середовищі иифрової науки. Методологічним базисом роботи обрано тріаду, що включає синергетичний, когнітивний і системний підходи та принципи до визначення конщептуальних засад функціонування бібліотеки як одного з елементів цифрової науки. Перший з них (синергетичний) спрямований на визначення інтеграиійних тенденцій взаємодії бібліотеки і иџиррової науки, другий (когнітивний) - на сприяння обміну знаннями між вченими в наукових комунікаціях, а третій (системний) - на трансформацію бібліотеки з інфраструктурного елемента науки в учасника дослідницької діяльності на всіх ї̈ етапах - від формування первинних даних до отримання та поширення нових знань. Наукова новизна роботи полягає в системному аналізі інтеграџійних тенденџій розвитку науково-дослідної та бібліотечноінформаційної діяльності й обтрунтуванні принципової необхідності участі бібліотеки в формуванні первинних досліднищьких даних і розвитку інформаційно-аналітичних досліджень у цифрових ресурсах бібліотек для виявлення в них латентних закономірностей і отримання нових знань. Новими є підходи до поглиблення уявлень щодо організації в бібліотеках віртуальних інфометричних лабораторій та когнітивна концепція організації взасмодії в системі «цифрова наука - бібліотека - дослідник». Основний науковий результат - концептуальна модель бібліотеки в середовищі цицррової науки розкриває в концентрованому вигляді закладені підходи до теоретико-методологічного обтрунтування стратегіі іï структурно-функиіональних трансформацій. Висновки. Головний висновок - необхідність спрямування вектора розвитку бібліотеки в середовищі цифрової науки на активізаџію участі в дослідницьких прочесах, запровадження високотехнологічних схем формування інформачійної бази иифрової науки та проведення в ній бібліо-, наукометричних та інфометричних досліджень.

Ключові слова: ичиррова наука, бібліотека, концептуальна модель, синергія, віртуальна лабораторія.

Копанева Виктория Александровна, кандидат исторических наук, директор Научной библиотеки

Национальной академии руководящих кадров культуры и искусств

\section{КОНЦЕПТУАЛЬНАЯ МОДЕЛЬ БИБЛИОТЕКИ В СРЕДЕ ЦИФРОВОЙ НАУКИ}

Цель работы - исследование направлено на определение и кониентрированное представление функциональной структуры библиотеки, основное назначение которой состоит в обеспечении системно-интеграционного взаимодействия научно-исследовательской и библиотечноинформационной деятельности в среде иифровой науки. Методологическим базисом работы выбрана триада, включающая синергетический, когнитивный и системный подходы и принщипы к 
определению кониептуальных основ функиионирования библиотеки как одного из элементов ичифровой науки. Первый из них (синергетический) направлен на определение интеграционных тендениий взаимодействия библиотеки и иифровой науки, второй (когнитивный) - на содействие обмену знаниями между учеными в научных коммуникациях, а третий (системный) - на трансформацию библиотеки с инфраструктурного элемента науки в участника исследовательской деятельности на всех ее этапах - от формирования первичных данных до извлечения и распространения новых знаний. Научная новизна работы заключается в системном анализе интеграционных тендениий развития научно-исследовательской и библиотечно-информационной деятельности и обосновании принципиальной необходимости участия библиотеки в формировании первичных исследовательских данных и развития информационно-аналитических исследований в цифровых ресурсах библиотек для выявления в них латентных закономерностей и получения новых знаний. Новыми есть подходы к углублению представлений об организации в библиотеках виртуальных инфометричних лабораторий и когнитивной конщепции организации взаимодействия в системе «ичфровая наука - библиотека - исследователь». Основной научный результат - концептуальная модель библиотеки в среде ичирровой науки раскрывает в концентрированном виде заложеные подходы $\kappa$ теоретико-методологическому обоснованию стратегии ее структурно-функииональных трансформаций. Выводы. Главный вывод - необходимость направления вектора развития библиотеки в среде иифровой науки на активизацию участия в исследовательских процесах, внедрение высокотехнологичных схем формирования информащионной базы циифровой науки и проведения в ней библио-, наукометрических и инфометричних исследований.

Ключевые слова: ицфровая наука, библиотека, концептуальная модель, синергия, виртуальная лаборатория.

Kopaneva Victoria,

$\mathrm{PhD}$ in History,

Director of the Scientific Library

National Academy of Culture and Arts Management

\section{CONCEPTUAL MODEL OF THE LIBRARY IN THE ENVIRONMENT OF DIGITAL SCIENCE}

The purpose of the article is to analyze the definition and the concentrated presentation of the functional structure of the library. Its main goal is to ensure system-integration interaction between the scientific and research activity and the library-information activities in the environment of digital science. The methodology of the research is the triad, which includes synergetic, cognitive, and systemic approaches and principles to define the conceptual foundations of the functioning of the library as one of the elements of digital science. The first (synergetic) is aimed at the determination of the integration trends of the library and digital science interaction. The second (cognitive) one contributes to the facilitation of the knowledge exchange among the scientists in the scientific libraries. The third (system) one is aimed at the transformation of the library into the participant of the research activities at all their stages - from the formation of primary data to the extraction and dissemination of new knowledge. The scientific novelty of the research includes the systematic analysis of the integration trends in the development of the scientific-research and librarian-information activities and the substantiation of the fundamental need for the participation of the library in the formation of primary research data and the development of information and analytical studies in digital library resources to identify latent patterns in them and get new knowledge. There are new approaches to deep the notions, dealt with the organization of the virtual infometric laboratories in libraries, and the cognitive conception of the organization of the interaction in the system "digital science - library - researcher.» The main scientific result is the fact that the conceptual model of the library in the environment of digital science reveals the basic approaches to the theoretical and methodological substantiation of the strategy of its structural and functional transformations in a concentrated form. Conclusions. The main conclusion is the need to direct the vector of development of the library in the digital science environment to intensify its participation in the research processes, introduce high-tech schemes for the formation of the digital science information base, and conduct biblio-, scientometric and infometric researches in it.

Key words: digital science, library, conceptual model, synergy, virtual laboratory. 
Актуальність теми дослідження. У абстрагованому й узагальненому вигляді концептуальна модель - це змістовне представлення структури і функцій системи без їх конкретного розкриття та деталізації. У концептуальній моделі наводяться основні відомості про систему, iї базові елементи та найважливіші зв'язки між ними. Процес створення такої моделі наразі не формалізовано, тобто не існує чітких правил іï побудови.

Основна проблема при створенні концептуальної моделі полягає в знаходженні компромісу між ії наочністю та точністю. На сьогодні існує низка теоретичних напрацювань 3 цієї проблеми, але їх важко застосувати для вирішення конкретного завдання. Тому розробникам моделі необхідно керуватись при прийнятті основних проектних рішень своїми знаннями, досвідом, інтуїцією та думкою експертів. Процес створення концептуальної моделі, ймовірно, ніколи не зможе бути повністю формалізований. Важко сформулювати набір простих правил, виконуючи які можна створити якісну концептуальну модель системи. Саме тому іноді стверджують, що моделювання $є$ не тільки наукою, а й мистецтвом. У процесі розробки концептуальної моделі вона може багаторазово коригуватися та уточнюватися. Завдяки цьому її адекватність (відповідність предметній сфері) підвищуватиметься.

Метою дослідження $\epsilon$ визначення та представлення функціональної структури бібліотеки, основне призначення якої полягає в забезпеченні системно-інтеграційної взаємодії науково-дослідної і бібліотечно-інформаційної діяльності в середовищі цифрової науки.

Виклад основного матеріалу. Концептуальною моделлю сучасної бібліотеки можна вважати іiі визначення, наведене в чинному Законі України «Про бібліотеки і бібліотечну справу»: бібліотека це «... інформаційний, культурний, освітній заклад (установа, організація) або структурний підрозділ, що має упорядкований фонд документів, доступ до інших джерел інформації та головним завданням якого є забезпечення інформаційних, науково-дослідних, освітніх, культурних та інших потреб користувачів бібліотеки» [1]. Дане визначення - концентроване представлення iï суспільного призначення, структури та функцій, сформульоване на основі доробок бібліотекознавства XX ст. Його потрібно розглядати одним із основних джерел для визначення концептуальної моделі бібліотеки в середовищі цифрової науки.

Викликає зацікавленість феномен зародження та існування в давнину Александрійської бібліотеки (III ст. до н. е. - IV ст. н. е.), принципи діяльності та функції якої в певній мірі відповідали не лише зазначеному вище визначенню, а й мають слугувати джерельною базою для розбудови наукової бібліотеки XXI ст. Заснування Александрійської бібліотеки нащадками Олександра Македонського було обумовлено їх прагненням пропагувати елліністичну культуру в усьому світі відомому на той час. Таке прагнення, що отримало назву «програми культурного імперіалізму» [2], спонукало збирання інформації для ії бібліотечних фондів як від греків, так і з більш далеких та давніх царств Близького Сходу. Наявність бібліотеки сприяла підвищенню престижу правителя, можливості отримання ним інформаційно-аналітичної підтримки в питаннях управління територіями та формуванню позитивного іміджу країни. Тому в ті часи кожний великий елліністичний центр приділяв увагу створенню власного зібрання джерел інформації. Александрійська бібліотека була безпрецедентною за масштабами: iï покровителі (династія Птолемеїв) на відміну від своїх попередників та сучасників прагнули створити сховище всіх знань. Вислів «хто володіє інформацією, той володіє світом» 3'явився в XX ст., однак розуміння його сутності було й у давнину - наведений вислів був принципом практичної діяльності з формування та організації багатоаспектного використання сховища наявних у той час інформаційних ресурсів.

Принциповою особливістю бібліотеки була ії інтеграція з Александрійським мусейоном (Mouseion) - одним із головних культурних центрів античності. Бібліотека і Мусейон створювалися майже одночасно і доповнювали один одного. Бібліотека зосереджувалась на інформаційному забезпеченні правителів i еліти тогочасного суспільства, а Мусейон був культовим закладом, що пропагував «ідеологічні» цінності династії Птолемеїв. Поклоніння цим цінностям носило не схоластичний характер, а було спрямовано на досягнення 
практичних цілей і здійснювалось у формі різноманітних наукових та літературних диспутів штатних учених і літераторів.

За обсягом фондів Александрійська бібліотека не мала рівних в еллінічному світі - від 50 тис. до 700 тис. сувоїв (за різними оцінками). Свідченням її авторитетності є той факт, що очільник бібліотеки як правило був і вихователем спадкоємця престолу. Віддаючи належне обсягу цього інформаційному ресурсу, слід наголосити: світову славу бібліотека отримала завдяки видатним ученим і митцям, які працювали в її стінах кілька тисяч років тому, та створеним ними науковим і мистецьким творам. Саме в стінах бібліотеки Евклідом (бл. 365 - бл. 300 до н. е.) були створено засади математики, Ератосфеном (бл. 275 - бл. 194 до н. е.) вперше визначено діаметр земної кулі, Клавдієм Птолемеєм написано трактат «Альмагест», що понад тисячоліття був класичною основою астрономічних знань.

Навіть цих трьох імен досить для твердження, що Александрійська бібліотека в сучасному розумінні була складовою повноцінної академії наук (це твердження можна поставити під сумнів - в ті часи, ймовірніше, академія існувала в стінах бібліотеки, адже навіть самого терміну «академія наук» ще не існувало). Потрібно також відзначити, що в ній Аполлоном Родоським (бл. 265 - бл. 215 до н. е.) створено «Аргонавтику», зусиллями Зенодота Ефеського (бл. 325 - 260 до н. е.) та його послідовників започатковано філологію: граматику, критику тексту, літературну критику тощо. Однин із очільників бібліотеки поет Каллімах (бл. 310 - бл. 240 до н. е.) склав іiі анотований каталог, який налічував 120 сувоїв. Тому його справедливо вважають першим бібліографом-практиком, хоча реалізація такого твору потребувала й значних теоретичних розвідок, яких раніше ніхто не проводив.

3 Александрійською бібліотекою пов'язано існування навчального закладу: одним 3 його випускників $€$ Архімед (287 - 212 до н. е.) - математик, механік, інженер, який сформулював закон про дію на занурене в рідину тіло виштовхуючої сили, що дорівнює масі витісненої рідини.

Однак, слід зазначити, що стародавні тексти збереглися не завдяки Александрійській та іншим античним бібліотекам. Пам'ять про ті часи дійшла до сьогодення завдяки виснажливій праці з копіювання наявних матеріалів спочатку професійними писарями римського періоду на папірус, а потім ченцями в середні століття на пергамент.

У цілому діяльність бібліотеки включала як закладене в чинному Законі України «Про бібліотеки та бібліотечну справу» «... забезпечення інформаційних, науково-дослідних, освітніх, культурних та інших потреб користувачів бібліотеки» [1], так і реалізацію низки споріднених функцій, не передбачених у цьому нормативному акті. Серед них:

- проведення досліджень з усіх галузей знань, а не лише їх інформаційне супроводження;

- підготовка фахівців вищої кваліфікації, а не тільки формування та підтримку освітньої джерельної бази;

- надання владним структурам спеціалізованої аналітичної інформації;

- підтримка культурної експансії елліністичних цінностей як зразків для інших країн і територій, що свідчить про наявність за часів династії Птолемеїв інтегруючих світоглядних орієнтирів, сукупність яких можна розглядати як тогочасну «національну ідею» [2].

Концептуальну модель Александрійської бібліотеки можна вважати першим прообразом бібліотеки цифрової науки, оскільки вона була інтегрована зі структурами, де проводили фундаментальні дослідження та отримували теоретичні результати світового рівня, створювали шедеври мистецтва, здійснювали підготовку кадрів вищої кваліфікації. Слід додати, що враховуючи роль останньої для світової цивілізації за ініціативою ЮНЕСКО був започаткований міжнародний проект побудови нової споруди бібліотеки, урочисто відкритої в 2003 р.

Безперечна необхідність урахування позитивних рис Александрійскої бібліотеки, концептуальна модель якої виглядає в певних аспектах більш прогресивною, ніж у бібліотек XX ст. Водночас слід відзначити кардинальну відмінність організаційно-технологічних можливостей інформаційного суспільства XXI ст. від можливостей суспільства античних часів. Перш за все, для сьогодення характерна на- 
явність системи бібліотек, об'єднаних загальною метою багатоаспектного сприяння розвитку суспільства. Ця система поділяється на підсистеми, кожна з яких має явно виражені специфічні властивості та функції. Одна з них - система наукових бібліотек. Вона входить як складова до системи більш високого рівня системи науки та освіти. В основу функціонування та розвитку наукових бібліотек покладено головний системоутворюючий принцип - взаємодія. Кожна окрема бібліотека і навіть відомча бібліотечна мережа не має такої сукупності ресурсів, яка здатна задовольнити інформаційні потреби своїх користувачів. I тільки в рамках певних взаємозв'язків бібліотеки отримують таку можливість.

Теоретичну базу для організації таких взаємозв'язків розроблено багатьма бібліотекознавцями. Серед них слід відзначити праці М. Карташова, який створив і апробував концепцію бібліотечно-територіальних комплексів [3]. Їх сутність - відомча централізація і регіональна кооперація бібліотек. У таких комплексах спрацьовують синергетичні механізми, які забезпечують досягнення інформаційного потенціалу комплексу більшого за сукупність потенціалів окремо взятих бібліотек. Завдяки цьому створюються передумови більш повного задоволення інформаційних потреб суспільства при менших сукупних витратах матеріальних, фінансових і трудових ресурсів.

Витоками необхідності інтеграції наукових бібліотек є принципова системність науки та наукового знання. Наразі руйнуються і становляться більш гнучкими й відносними межі між теоретичними та прикладними, технічними й соціогуманітарними науками, між природознавством і суспільствознавством. Складні комплексні проблеми становляться інтегруючими центрами, навколо яких групуються десятки наукових дисциплін (наприклад, комплекс наук про життя). Водночас відбуваються наскрізні процеси математизації, інформатизації, технізації та гуманізації науки. Виникають і набувають розвитку нові міждисциплінарні підходи до проведення досліджень, поглиблюється взаємопроникнення наук, утворення міждисциплінарних мереж. У зв’язку з цим зростає нагальність організації оперативної взаємодії наукових бібліотек різних систем і відомств для задоволення інформаційних потреб учених та фахівців як з вузькоспеціалізованої, так і широкої комплексної тематики.

Головною передумовою гармонізації відомчих та міжвідомчих інтересів бібліотек i формування бібліотечно-територіального комплексу є вироблення рекомендацій, що базуватимуться не на адміністративних засобах впливу, а на пошуку основи для добровільної домовленості, що має показати всім учасникам системи вигідні для себе напрями розвитку. Вони мають сприяти координації комплектування інформаційних ресурсів, оптимізації депозитарного зберігання фондів, організації електронної доставки документів, взаємодії в сфері сканування фондів, бібліографічної діяльності, наукової та методичної роботи.

Для того, щоб незалежні наукові бібліотеки стали частинами єдиного якісно нового бібліотечного організму, необхідна наявність між ними спеціалізації, тобто розподілу праці 3 формування сукупних ресурсів і організації бібліотечних сервісів 3 інформаційного обслуговування користувачів [3]. В Україні така спеціалізація вже існує: прикладом можуть слугувати головні бібліотеки національної та національних галузевих академій наук і координаційні центри бібліотек ЗВО.

Можна констатувати високий рівень теоретичного обгрунтування проблематики формування бібліотечно-територіальних комплексів і системи бібліотек у цілому для умов техногенної індустріальної цивілізації. Тому безперечною вбачається доцільність їх урахування при формулюванні концептуальних положень бібліотеки цифрової науки. Однак ще більш нагальною є необхідність узгодження згаданих положень 3 новими суспільними викликами, пов'язаними 3 появою в другій половині $\mathrm{XX}$ ст. терміну «постіндустріальне суспільство» та наступного поширення термінів «інформаційне суспільство» та «суспільство знань».

Ідея інформаційного суспільства набула міжнародного визнання в 2000 році, коли в Окінаві лідери «великої вісімки» підписали Хартію глобального інформаційного суспільства. У Хартії декларувалося: «Інформаційнокомунікаційні технології $є$ одним 3 найбільш 
важливих факторів, що впливають на формування суспільства XXI ст. Їх революційний вплив стосується способу життя людей, ïх освіти і роботи, а також взаємодії уряду та громадянського суспільства. Перед усіма нами відкриваються величезні можливості» [4]. У 2003 р. в Женеві відбувся Всесвітній саміт 3 інформаційного суспільства, де були прийнято «Декларація принципів» [5], яка розвивала положення Окинавської хартії. У 2005 р. Всесвітній форум на найвищому рівні було продовжено в Тунісі, де були прийнято «Туніську програму для інформаційного суспільства» [6], в якій містилися пропозиції щодо розв'язання ключових проблем реалізації глобального інформаційного суспільства.

Ідея суспільства знань не може похвалитися настільки пильною увагою державних діячів, проте в філософсько-гуманітарних колах вона обговорювалася досить інтенсивно [7]. У 2005 році був оприлюднена Всесвітня доповідь ЮНЕСКО «До суспільств знання» [8], в складанні якої взяли участь провідні філософи і соціальні теоретики сучасності: Ж. Дерріда, М. Кастельс, Ю. Крістєва та ін. У доповіді розглядається перспектива переходу від глобального інформаційного суспільства до суспільств знань. Автори доповіді виходять 3 постулату, що інформація - інструмент знання, а не саме знання, оскільки інформація - це товар, який купується та продається на відповідному ринку, а знання є суспільним надбанням, яке має бути доступним для кожного. Гуманістична позиція авторів проявляється в наступних принципах [8]:

- по перше, суспільство знань мислиться як глобальне та мережеве, але не допускає насаджувану комп'ютерно-телекомунікаційними технологіями уніфікацію способу мислення та життя. Необхідно зберегти різноманіття і багатомовність культур. Саме тому в доповіді йдеться не про одне, еталонне «суспільство знання», а про розмаїття «суспільств знань», кожне з яких має власні перевагами;

- по-друге, надання пріоритетів духовному розвитку особистості, щоб кожна людина вільно орієнтувався в потоці інформації і відрізняла корисну інформацію від непотрібної. Звідси девіз «освіта для всіх на протязі всього життя»;
- по-третє, ліквідація соціальної і міжнародної нерівності в доступі до знань;

- по-четверте, забезпечення прав людини на свободу висловлення поглядів, на безплатну базову освіту, на участь у культурному житті суспільства і в науковому прогресі;

- i, насамкінець по-п’яте, автори переконані, що знання не можна перетворювати в товар, тому надмірна комерціалізація доступу до знань розглядається ними як серйозна загроза для людства.

Ці гуманістичні принципи добре узгоджуються 3 місією, традиційно виконуваною бібліотечною системою.

Значення доповіді полягає не тільки в тому, що вона привернула увагу світового співтовариства до негативних наслідків комерційної інформатизації та стимулювала дискусію навколо суті «суспільства знань». Більш важливим за схоластичні суперечки вбачається гуманістичний пафос доповіді, прагнення подолати технократичну однобічність, присутню в більшості публікацій про інформаційне суспільство. 3 цих позицій будемо розглядати підходи до розвитку концептуальних засад функціонування Александрійської бібліотеки античних часів i бібліотечно-територіальних комплексів XX ст. для забезпечення системно-інтеграційної взаємодії бібліотеки з цифровою наукою.

Перш за все зазначимо, що темпи функціонально-структурних трансформацій наукових бібліотек відстають від динаміки цифровізації суспільства. Це приводить до того, що вчені і науково-педагогічні працівники задовольняють все більшу частку своїх інформаційних потреб без звернення до бібліотек, насамперед, шляхом використання ресурсів глобальних комп'ютерних мереж. Значній частці цих актуальних для науки ресурсів бібліотеки не приділяють належної уваги. Це, зокрема, первинні дослідницькі (експериментальні) дані та плинні ресурси Інтернету наукової та суспільно значущої спрямованості.

Крім того, сучасні наукові бібліотеки, зосередившись на інформаційному забезпеченні досліджень, стали інфраструктурними елементами науки. У Александрійській бібліотеці фундаментальні дослідження проводились у її стінах - це був єдиний організм. Саме синергія бібліотеки і науки дозволила ство- 
рити унікальну інституцію, функціональноструктурна організація якої значно випередила час. Безперечною є потреба посилення в концептуальній моделі бібліотеки цифрової науки дослідницького аспекту діяльності, насамперед, з використанням наукомістких технологій. Ці технології мають забезпечити реалізацію специфічних фаз дослідження: консолідації даних з різних джерел, відбір базових даних для інформаційного аналізу надвеликих масивах, вибору адекватних інструментальних засобів і методів їх комбінованого використання, аналізу різних форм візуалізації обчислень тощо [9].

Ефективність реалізації згаданих технологій в значній мірі залежить від можливості їх використання в системі наукових комунікацій. Для цього в концептуальній моделі мають бути враховані когнітивні аспекти поширення інформації, що дозволить перейти від передачі масивів даних до сприяння в отриманні особою нових знань. У загальному випадку інформація, отримана в результаті вербалізації та документування знань автора, не є повністю тотожною цим знанням. Така аналогія має місце і з процесом усвідомлення користувачем зовнішньої інформації: так, отримані ним знання з урахуванням когнітивних аспектів сприйняття цієї інформації також не можуть бути тотожними їй. Саме тому процес передачі знань від автора до користувача в процесі наукової комунікації супроводжується певними втратами інформації, тобто є ентропійним. Для зменшення інформаційної ентропії необхідно використання когнітивноорієнтовних ресурсів. Такими є, наприклад, відомості про авторів документальної інформації, понятійно-категоріальний апарат предметної галузі та інші дані, що становлять основу довідково-бібліографічного апарату бібліотеки.

Як зазначалось вище, однією $з$ функцій Александрійської бібліотеки була «програма культурного імперіалізму» [2], що передбачала пропагування цінностей династії Птоломеїв - тогочасної «національної ідеї». Це було не останньою причиною належної уваги до бібліотеки та відповідного їі «фінансування». Наразі в Україні змістовна державна політика розвитку науки та освіти підмінена «оптимі- заційними» заходами, орієнтованими на зменшення коштів, що виділяються на дослідження. Значною мірою причиною такої ситуації $\epsilon$ відсутність конструктивного діалогу між науковою спільнотою, системою управління наукою та суспільством у цілому. Для налагодження діалогу до числа концептуальних положень бібліотеки цифрової науки слід включити надання суспільству цілісного уявлення про наукове та науково-педагогічне середовище України, стан науки, тенденції її розвитку та спроможність сприяти розвитку економіки і вирішенню соціальних завдань.

Наукова новизна роботи полягає в системному аналізі інтеграційних тенденцій розвитку науково-дослідної та бібліотечноінформаційної діяльності й обгрунтуванні принципової необхідності участі бібліотеки в формуванні первинних дослідницьких даних і розвитку інформаційно-аналітичних досліджень у цифрових ресурсах бібліотек для виявлення в них латентних закономірностей $\mathrm{i}$ отримання нових знань. Новими є підходи до поглиблення уявлень щодо організації в бібліотеках віртуальних інфометричних лабораторій та когнітивна концепція організації взаємодії в системі «циифрова наука - бібліотека - дослідник». Основний науковий результат - концептуальна модель бібліотеки в середовищі цифрової науки, в якій у концентрованому вигляді закладено підходи до теоретикометодологічного обгрунтування стратегіï iii структурно-функціональних трансформацій.

Висновки. Сукупність викладених вимоги до функціонально-структурних трансформацій бібліотеки в середовищі цифрової науки дозволяють сформулювати iï концептуальну модель.

Бібліотека в середовищі цифрової науки - установа або структурний підрозділ установи, що забезпечує формування впорядкованого фонду первинних дослідницьких даних і виявлення в ньому нових закономірностей, сприяє конвергенції інформаційних і когнітивних технологій для продукування знань, синергія яких буде спрямована на функціональну трансформацію бібліотеки 3 інфраструктурного елемента науки в учасника дослідницької діяльності. 


\section{Список використанних джерел}

1. Закон України Про бібліотеки і бібліотечну справу [Електронний ресурс]: за станом на 27 січня 1995 року. - Режим доступу: https://zakon.rada.gov.ua/laws/show/32/95-вр. - Назва з екрана.

2. The Library of Alexandria: Centre of Learning in the Ancient World / Roy M. (ed.). New York : I.B.Tauris Publishers, 2004. 196 p.

3. Карташов Н. С. Формирование библиотечно-территориальных комплексов. Новосибирск : Наука, 1978. 238 c.

4. Окінавська хартія глобального інформаційного суспільства: за станом на 22 липня 2000 року. URL: https://zakon.rada.gov.ua/laws/show/998_163 (дата звернення: листопад 2019)

5. Женевська Декларація принципів: за станом на 12 грудня 2003 року. URL: https://informationsociety. wordpress.com/basics/wsis_outcomes/dp/ (дата звернення: листопад 2019)

6. Туніська програма для інформаційного суспільства: за станом на 18 листопада 2005 року. URL: http://old.apitu.org.ua/wsis/tp (дата звернення: листопад 2019)

7. Соколов А. В. Миражи. Россия. 2045. Библиофутурологическая лекция. Научные и технические библиотеки. 2015. № 10. С. 53-66.

8. К обществам знания: Всемирный доклад ЮНЕСКО. Париж: Изд-во ЮНЕСКО, 2005. 240 с.

9. Соловяненко Д. Академічні бібліотеки в новому соціотехнічному вимірі: Частина четверта. Сучасний рівень дискурсу академічного бібліотекознавства та поступ е-науки. Бібліотечний вісник. 2011. № 11. С. 8-24.

\section{References}

1. Law of Ukraine on Libraries and Library Affairs. (2015). Retrieved from: https://zakon.rada.gov.ua/ laws/show/32/95-вр [in Ukrainian].

2. Roy M. (2004). The Library of Alexandria: Centre of Learning in the Ancient World. New York [in English].

3. Kartashov N. S. (1978). Formation of library-territorial complexes. Novosibirsk [in Russian].

4. Okinawa Charter of the Global Information Society (2000). Retrieved from: URL: https://zakon.rada. gov.ua/laws/show/998 163 [in Ukrainian].

5. Geneva Declaration of Principles (2003). Retrieved from: URL: https://informationsociety.wordpress. com/basics/wsis_outcomes/dp/ [in Ukrainian].

6. Tunisian program for the Information Society (2005). Retrieved from: URL: http://old.apitu.org.ua/ wsis/tp [in Ukrainian].

7. Sokolov, A. V. (2015). Mirages. Russia. 2045. Bibliotecologia lecture. Nauchnyie i tehnicheskie biblioteki, 10, 53-66 [in Russian].

8. Towards Knowledge Societies: UNESCO World Report (2005). Paris [in Russian].

9. Solovyanenko, D. (2011). Academic libraries in the new socoteco dimension: Part four. The current level of discourse of the academic library studies and the promotion of e-science. Бібліотечний вісник, 1, 8-24 [in Ukrainian]. 